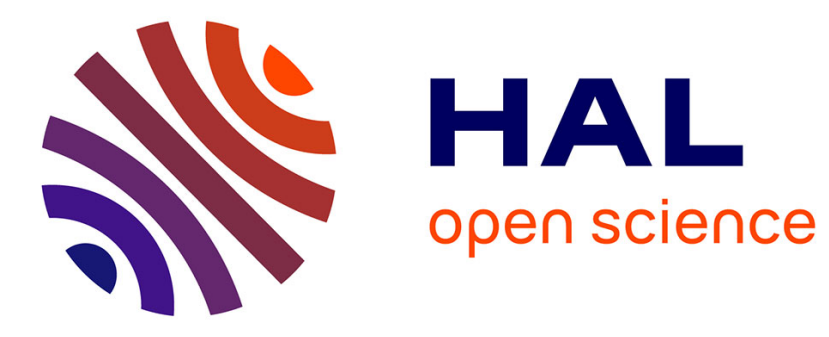

\title{
Systematic literature review of sustainable repair shops
} Rony Arsène Djeunang Mezafack, Maria Di Mascolo, Zineb Simeu-Abazi

\section{To cite this version:}

Rony Arsène Djeunang Mezafack, Maria Di Mascolo, Zineb Simeu-Abazi. Systematic literature review of sustainable repair shops. ICCAD 2020 - 4th International Conference on Control, Automation and Diagnosis, Oct 2020, Paris, France. 10.1109/ICCAD49821.2020.9260527 . hal-03033322

\section{HAL Id: hal-03033322 \\ https://hal.science/hal-03033322}

Submitted on 1 Dec 2020

HAL is a multi-disciplinary open access archive for the deposit and dissemination of scientific research documents, whether they are published or not. The documents may come from teaching and research institutions in France or abroad, or from public or private research centers.
L'archive ouverte pluridisciplinaire HAL, est destinée au dépôt et à la diffusion de documents scientifiques de niveau recherche, publiés ou non, émanant des établissements d'enseignement et de recherche français ou étrangers, des laboratoires publics ou privés. 


\title{
Systematic literature review of sustainable repair shops
}

\author{
Rony Arsène DJEUNANG MEZAFACK, Maria DI MASCOLO, Zineb SIMEU-ABAZI \\ Univ. Grenoble Alpes, CNRS, Grenoble INP*, G-SCOP, 38000 Grenoble, France \\ *Institute of Engineering Univ. Grenoble Alpes
}

\begin{abstract}
The performance evaluation or the optimization of the maintenance activities inside the repair shop is crucial for the life of all the manufacturers. Repair shops aim to detect the origin of the failure on the faulty equipment with two alternatives: to restore its operation (corrective maintenance) or to take some components for another reuse and for what remains to recover material [3]. It is the set of resources required for maintenance actions, such as maintenance operators, the different intervention stations necessary for the different stages of repair, whose objective is to direct the faulty equipment towards a repair or reuse. The purpose of this paper is to conduct a literature review of repair shop improvements, when taking into account the context of Circular Economy which allows firstly, for repairable defective equipment, to be returned to serviceable condition and secondly, for non-repairable equipment, to identify reusable components that will be used to supply the spare parts warehouse.
\end{abstract}

Keywords-Repair by replacement, Logistic; Maintenance workshop; Reuse; Recycling; Remanufacturing; Circular economy

\section{INTRODUCTION}

In almost all the manufacturing companies, maintenance operations involve huge costs that can represent between $15 \%$ and $70 \%$ of the total production budget [1]. It is the case of non-military equipment, which spent more than $\$ 9$ billion from a turnover generated by the component repairs in 2015 [2]. In order to satisfy customers and keep up with the competition, the lives of industries depend on the availability of high-value capital assets to provide their services or manufacture their products [3]. The last decades have been characterized by an exceptional change in the regulation of maintenance actions and associated budgets [4]. Thus, many companies improved continuously and progressively their maintenance department [5]. Maintenance activities then became more complex, prompting manufacturers to centralize them, resulting in the concept of repair shops [6]. When failed equipment arrives at the centralized maintenance workshop, its sojourn time depends on the scheduling policies, the repair capacity and the sizing of the spare parts store. In the same context of economic growth, the circular economy aims to replace the "end-of-life concept" by closing material loops and extending product life [7]. It is one of the recent and promising solutions to deal with the limitations of the repair shops, allowing the reuse [8], the remanufacturing [9] or the recycling [10] of some components in a repair shop. Indeed, one of the biggest challenges of Centralized Maintenance is to reduce the waste in terms of time and resources used in maintenance activities [5]. Unfortunately, existing frameworks simply consider equipment supplied by multi-site production as defective or not. However, defective equipment may have components in different states of availability. Hence, these frameworks do not yet take into account the opportunity to reintegrate some components of this defective equipment into the value chain [11]. So, one interesting research question is: how can the repair shops are improved by integrating circular strategies? From this, we can identify three sub questions, which are: How should we design a better model for a repair shop? What are the different operations involved in a repair shop? What is the material flow inside repair shops? To answer these questions, this study aims at conducting a literature review focusing on the concepts of repair shop and circular economy. Our methodological approach is presented in section 2. It consists in, firstly, defining and combining the relevant keywords from the best journals, to search articles in defined databases. Afterwards, we use some filters, including and excluding criteria, in order to obtain representative and relevant papers of the literature. After filtering, we conduct a cross-analysis through-out resulting articles. Section 3 presents the results of our literature review, and the opportunities for future research are given in section 4 .

\section{RESEARCH METHODOLOGY}

\section{A. Defining and combining the relevant keywords}

This step is very important for our research as the foundation of the literature review. We choose to, firstly, have an overview of all the most used keywords in the best journals of our field. We use the "Scimago Journal \& Country Rank" to select the 25 most highly-ranked journals related to our subject area (Industrial and Manufacturing Engineering) following the approach described in [12] and [13]. Interested in the Circular Economy with the main topics of repair shops obtained from our above research sub-questions (Organization, Operation and Material flow), we choose manually the keywords presented in Table I from the 25 selected journals. Indeed, browsing manually the articles addressing repair shops in the most cited journals gives an overview of all the keywords used in the field by the authors. Then, we combine the selected keywords to explore the topics of sustainable repair shops in Table II. We finally obtain 56 different combinations of our 
keywords from the use of operators "AND" and "OR". Hence the search will be better specified, as presented in Fig. 1.

TABLE I. LIST OF KEYWORDS USED IN THE STUDY FIELD

\begin{tabular}{|c|c|c|c|}
\hline \multirow{2}{*}{$\begin{array}{l}\text { Circular } \\
\text { Economy }\end{array}$} & \multicolumn{3}{|c|}{ Repair shop } \\
\hline & Organization & Operation & Material flow \\
\hline $\begin{array}{l}\text { Circular Economy, } \\
\text { Recycling, } \\
\text { Repurposing, } \\
\text { Remanufacturing; } \\
\text { Reuse, } \\
\text { Sustainability; }\end{array}$ & $\begin{array}{l}\text { Maintenance } \\
\text { workshop(s), } \\
\text { Model, } \\
\text { Repair shop(s) }\end{array}$ & $\begin{array}{l}\text { Maintenance } \\
\text { Repair }\end{array}$ & $\begin{array}{l}\text { Inventory, } \\
\text { Logistic(s), } \\
\text { Spare part(s) }\end{array}$ \\
\hline
\end{tabular}

TABLE II.

COMBINATION OF KEYWORDS

\begin{tabular}{|c|c|c|c|}
\hline $\begin{array}{l}\text { Circular } \\
\text { Economy }\end{array}$ & Organization & Operation & $\begin{array}{l}\text { Material } \\
\text { flow }\end{array}$ \\
\hline $\begin{array}{l}\quad \text { (Circular } \\
\text { Economy } \\
\text { OR Sustainability } \\
\text { OR Reuse } \\
\text { OR Repurposing } \\
\text { OR Remanufacturing } \\
\text { OR Recycling) } \\
\text { AND } \\
\quad \text { (Maintenance } \\
\text { workshop(s) } \\
\text { OR Repair } \\
\text { shop(s)) }\end{array}$ & $\begin{array}{l}\text { Model } \\
\text { AND } \\
\quad \text { (Maintenance } \\
\text { workshop(s) } \\
\text { OR } \\
\text { Repair shop(s)) }\end{array}$ & $\begin{array}{l}\text { (Maintenance } \\
\text { OR Repair) } \\
\text { AND } \\
\text { (Maintenance } \\
\quad \text { workshop(s) } \\
\text { OR } \\
\text { Repair } \\
\text { shop(s)) }\end{array}$ & $\begin{array}{l}\quad \text { (Inventory } \\
\text { OR Logistic(s) } \\
\text { OR Spare-parts } \\
\text { OR } \\
\text { Spare } \\
\text { part(s)) } \\
\text { AND } \\
\text { (Maintenance } \\
\text { workshop(s) } \\
\text { OR } \\
\text { Repair shop(s)) }\end{array}$ \\
\hline
\end{tabular}

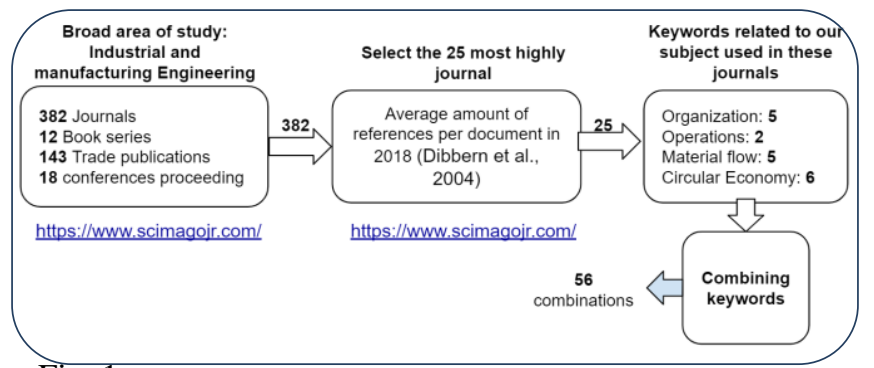

Fig. 1. Methodology to find the relevant keywords

\section{B. Research databases}

There are many sources where to find relevant articles, but the filters differ from one source to another. Since the search is automatic and among a large number of articles, we have chosen to retain only those sources that allow us to filter full texts, titles and abstracts, as presented in Table III.

TABLE III.

RESULTS OF THE SOURCES

\begin{tabular}{|l|c|c|}
\hline \multirow{2}{*}{ Sources } & \multicolumn{2}{|c|}{ Filters } \\
\cline { 2 - 3 } & Title or Abstract & Full text \\
\hline Emerald (emeraldinsight.com) & 18 & 90 \\
\hline IEEE (ieeexplore.ieee.org) & 6 & 9 \\
\hline Science Direct (Sciencedirect.com) & 69 & 1941 \\
\hline Web of Science (Grenoble online) & 222 & 240 \\
\hline Wiley (onlinelibrary.wiley.com) & 2 & 43 \\
\hline
\end{tabular}

For example, using the source Emerald, we found 90 articles containing at least one of the combined keywords in their full text and less than 18 articles containing these keywords in either their abstracts or their titles.

\section{Defining filters}

To find relevant articles for the systematic literature review, we use filters presented in Table IV. Indeed, progressively using exclusion and inclusion criteria, we take firstly all the papers concerned by our topic and which have at least one of the combined keywords in either their titles or their abstracts. Secondly, we remove manually all the duplicated items and proceeding papers. Thirdly we keep only the quantitative articles, and finally, we focus on the core activities of the repair shop (or maintenance workshop), which leads to 48 articles, as presented in Fig. 2.

TABLE IV

\begin{tabular}{|c|c|c|c|c|}
\hline $\mathbf{N}^{\circ}$ & Scope & Inclusion criteria & $\begin{array}{c}\text { Exclusion } \\
\text { criteria }\end{array}$ & $\begin{array}{c}\text { Results } \\
\text { (articles) }\end{array}$ \\
\hline 1 & Topic & $\begin{array}{l}\text { Finding the } \\
\text { combined } \\
\text { keywords in the } \\
\text { full text of articles }\end{array}$ & - & 2323 \\
\hline 2 & $\begin{array}{l}\text { Research } \\
\text { questions }\end{array}$ & $\begin{array}{l}\text { Finding } \\
\text { combined } \\
\text { keywords in the } \\
\text { title or abstract or } \\
\text { article keywords }\end{array}$ & - & 317 \\
\hline 3 & Relevance & - & $\begin{array}{l}\text { Duplicated } \\
\text { items and } \\
\text { proceeding } \\
\text { articles }\end{array}$ & 116 \\
\hline 5 & Methodology & Quantitative & Qualitative & 74 \\
\hline 4 & Focus & Repair shop items & - & 48 \\
\hline
\end{tabular}

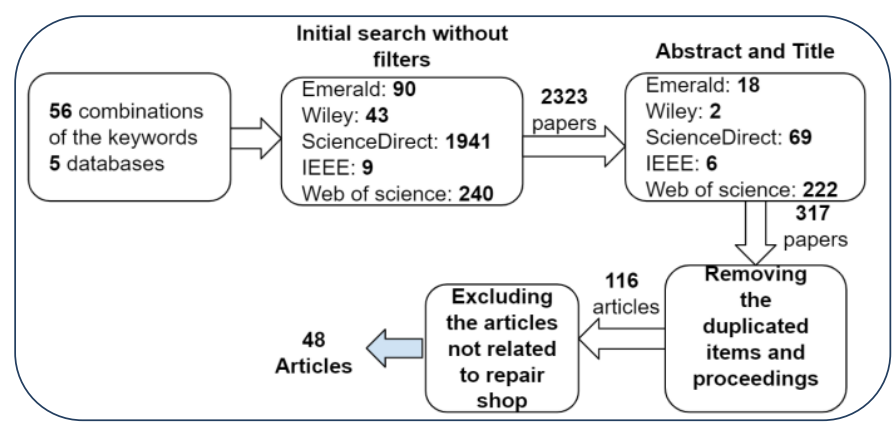

Fig. 2. Methodology to find the 48 relevant articles

\section{RESULTS OF CONTENT ANALYSIS}

The 48 articles under study have been written between 1984 and 2020, and can be classified into 3 main periods of time, as illustrated in Fig. 3. The first period, from 1984 to 2000 shows the first articles addressing repair shops activities, but with a low density of publication in time. The second, from 2000 to 
2007, is characterized by the increase of articles published on repair shops with at least one each year. The third period, from 2011 to 2020, is the most productive in terms of publications.

However, the implementation of circular strategies is not well studied yet. We just have 5 articles on this topic in the literature, since 2005, which represents less than $11 \%$ of articles, as shown in Table $\mathrm{V}$, which reports the different contributions of the articles under study, regarding the topics concerning the sustainable repair shops: organization, operation, material flow and circular economy. 2005, 2011, 2013, 2016 and 2019 are the years embedding all the topics with the highest level of publications.

In addition, on the one hand, without using Circular strategies, 41 articles address at least 2 topics, which represents $85 \%$ of all the articles and, on the other hand, the 5 remaining articles with the circular economy also address at least 2 other topics. Hence, regardless of the strategies used by the authors, they are already aiming to include all the aspects of repair shop activities in their studies.

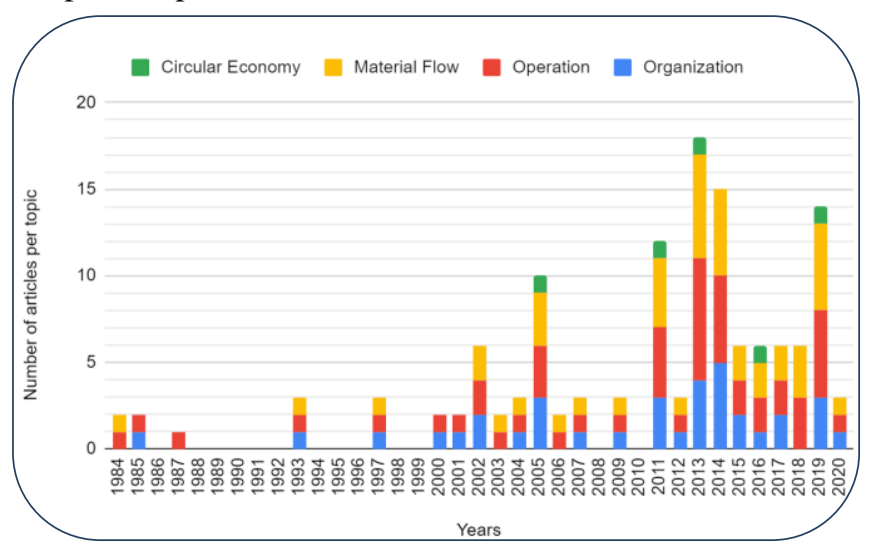

Fig. 3. Evolution of the articles through years (until end of February 2020)

To measure the impact of articles in the research community we decided to evaluate the average number of citations per year for each article. We select the most cited articles using the Pareto chart by showing $20 \%$ of the articles representing $80 \%$ of all the citations. Fig. 4 presents the results obtained for the articles addressing repair shops without circular strategies. Fig. 5 presents also the most cited articles addressing circular strategies. We observe more cited articles without circular strategies than articles with it, and there are no articles in both. We can observe that authors who address circular strategies are few and not very cited yet.

In Table VIII, we show the journals in which the studied articles are published. We can observe that most journals contain only one of these articles, and that IJPE and EJOR are the journals which contain the greatest number of articles in the studied area. We have also selected the most cited journals by calculating the average number of citations per year as criteria. IJPE is the most-cited journal for sustainable repair shops because it addresses both repair shop activities and circular strategies, as presented in Fig. 6 and Fig. 7.

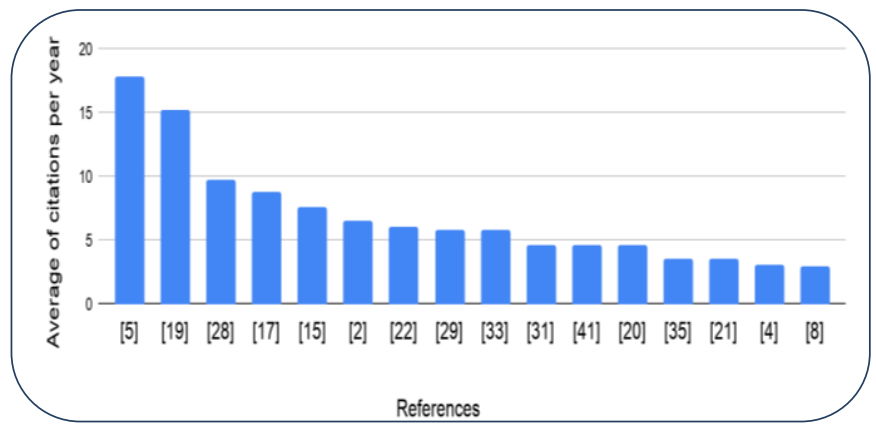

Fig. 4. The most cited articles without Circular strategies

TABLE V. REPARTITION AND CONTRIBUTION OF THE ARTICLES

\begin{tabular}{|c|c|c|c|c|c|c|}
\hline \multirow{2}{*}{$\begin{array}{l}\text { Or } \\
\text { gan } \\
\text { izat } \\
\text { ion }\end{array}$} & \multirow{2}{*}{$\begin{array}{c}\text { Op } \\
\text { era } \\
\text { tio } \\
\text { n }\end{array}$} & \multirow{2}{*}{$\begin{array}{l}\text { Mate } \\
\text { rial } \\
\text { flow }\end{array}$} & \multirow{2}{*}{$\begin{array}{c}\text { ar } \\
\text { Econo } \\
\text { my }\end{array}$} & \multicolumn{3}{|c|}{ Results } \\
\hline & & & & $N b^{\text {a. }}$ & $\%$ & References \\
\hline$\bullet$ & - & $\bullet$ & & 29 & 61 & $\begin{array}{c}{[2],[3],} \\
{[5],[6],} \\
{[8],[11],} \\
\text { from [14] } \\
\text { to }[23], \\
\text { from [25] } \\
\text { to [37] }\end{array}$ \\
\hline \multirow[t]{3}{*}{ - } & - & - & $\cdot$ & 2 & 4 & {$[38],[39]$} \\
\hline & - & $\bullet$ & & 9 & 19 & $\begin{array}{c}{[4], \text { from }} \\
{[40] \text { to }} \\
{[47]}\end{array}$ \\
\hline & - & - & - & 3 & 6 & $\begin{array}{c}9],[10], \\
{[48]}\end{array}$ \\
\hline \multirow[t]{2}{*}{$\bullet$} & 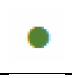 & & & 3 & 6 & $\begin{array}{c}\text { [49], [50], } \\
{[51]}\end{array}$ \\
\hline & $\bullet$ & & & 2 & 4 & {$[52],[53]$} \\
\hline $35^{\text {a. }}$ & $48^{\mathrm{a} .}$ & $42^{\mathrm{a} .}$ & $\begin{array}{c}5^{\text {a. }} \\
{[9],[10],} \\
{[48] \text { [38], }} \\
{[39]}\end{array}$ & 48 & $\begin{array}{c}100 \\
\%\end{array}$ & \\
\hline
\end{tabular}

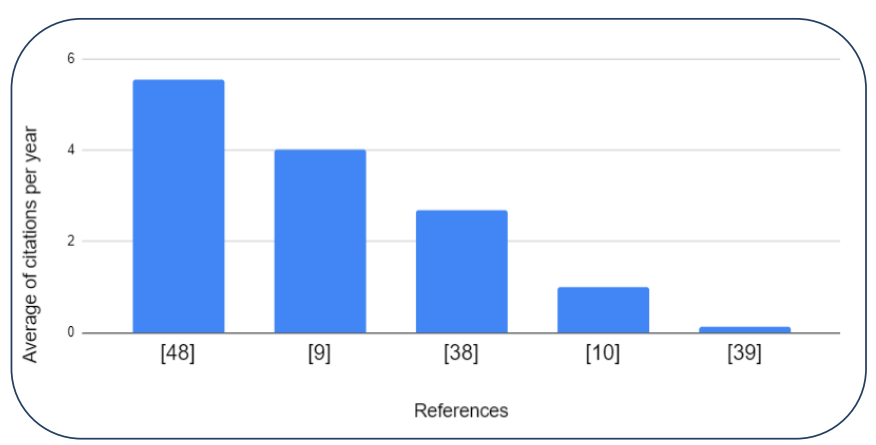

Fig. 5. The most cited articles with Circular strategies 


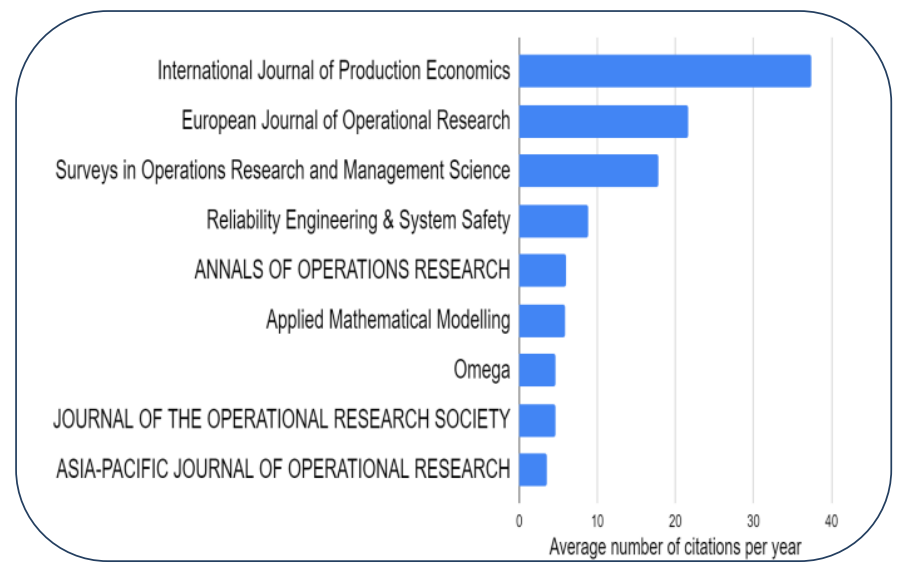

Fig. 6. The most cited journals without Circular strategies

In order to minimize the total costs of maintenance activities and increase the availability and the maintainability of the products, repair shops have always been continuously improved [15]. Indeed we find many approaches in the literature either for optimization or for performance evaluation, as presented in Tables VI and Table VII.

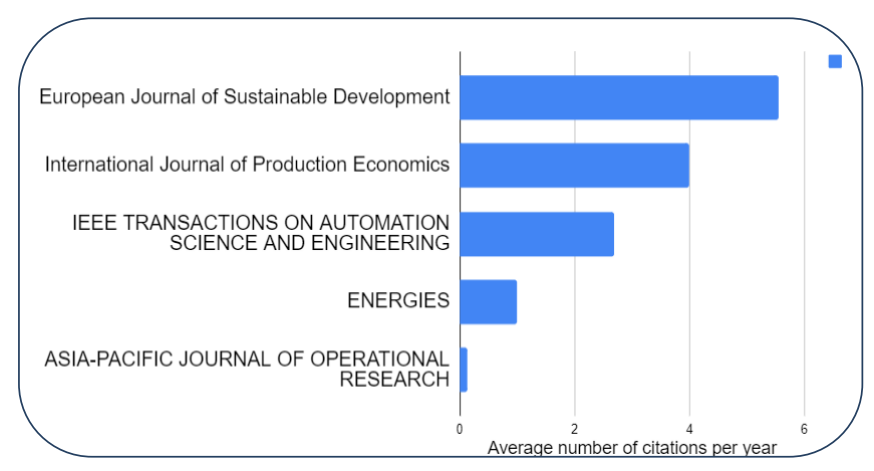

Fig. 7. The most cited journals with Circular strategies

Almost all the articles deal with these methods and just a few use case studies and real data such as [19], [22], [26], [31], [9], [10] and [48]. Queuing networks (15 articles) and Discrete event simulation ( 7 articles) are the most used models for performance evaluation, through an analytical method or a simulation, representing $44 \%$ of all the articles. Linear or Nonlinear Programming (15 articles) and Metric models (6 articles) are the most used algorithms for optimization representing $42 \%$ of all the articles. Circular Economy is not enough used yet, however in [39] authors use Stochastic Petri Nets for performance evaluation, in [9] Non-Linear programming for Optimization and performance evaluation combined to optimization in [38]. The articles [10] and [48] use a survey to evaluate the implementation of circular strategies in several companies.
TABLE VI. METHODS WITHOUT CIRCULAR ECONOMY USED BY THE AUTHORS

\begin{tabular}{|c|c|c|c|c|c|}
\hline \multirow[b]{2}{*}{$\begin{array}{l}\text { Without Circular } \\
\text { Economy }\end{array}$} & \multicolumn{2}{|c|}{$\begin{array}{c}\text { Performance } \\
\text { Evaluation }\end{array}$} & \multicolumn{3}{|c|}{ Optimization } \\
\hline & Analytical & Simulation & Exact & Heuristic I & letaheuristic \\
\hline $\begin{array}{c}{[16],[17],[21],} \\
{[25],[27],[28],} \\
{[30],[31],[33],} \\
{[35]}\end{array}$ & & & 0 & & \\
\hline $\begin{array}{c}\text { [8], [11], [20], } \\
{[23],[29],[46],} \\
{[51],[8]}\end{array}$ & - & ○ & & & \\
\hline $\begin{array}{c}15],[18],[19], \\
{[41],[45]}\end{array}$ & - & - & & - & \\
\hline $\begin{array}{c}2],[14],[34], \\
{[36],[53]}\end{array}$ & & & & & - \\
\hline $\begin{array}{c}{[3],[6],[50],} \\
{[52]}\end{array}$ & & - & & & \\
\hline $\begin{array}{c}5],[22],[37], \\
{[44]}\end{array}$ & & & & - & \\
\hline$[26],[40],[49]$ & & $\bullet$ & & $\odot$ & \\
\hline$[32],[42],[43]$ & - & 9 & - & & \\
\hline [4] & & - & - & & \\
\hline
\end{tabular}

TABLE VII. METHODS WITH CIRCULAR ECONOMY USED BY THE AUTHORS

\begin{tabular}{|c|c|c|c|c|c|}
\hline \multirow{2}{*}{$\begin{array}{c}\text { With } \\
\text { Circular } \\
\text { Economy }\end{array}$} & \multicolumn{2}{|c|}{$\begin{array}{c}\text { Performance } \\
\text { evaluation }\end{array}$} & \multicolumn{2}{|c|}{ Optimization } & \multirow{2}{*}{ Survey } \\
\hline & Analytical & Simulation & Exact & Heuristic & \\
\hline [39] & ○ & 0 & & & \\
\hline [9] & & & - & & \\
\hline$[38]$ & & 0 & & 0 & \\
\hline$[10],[48]$ & & & & & ○ \\
\hline
\end{tabular}

\section{CONCLUSION}

This article provides an overview and an analysis of the literature about the implementation of the circular economy in repair shops activities. Obviously, manufactured products have a limited lifetime, and the main purpose of repair shops is to extend it by taking out the failed components and replacing them with ready-for-use components (repairables [2]) based on their condition [3]. Since 1984, the repair shops 
strategies have progressively evolved, the first article and others deal with the improvement of the scheduling and the spare stocking policies [40]. Many others evaluate the performance or optimize the repair capacity of repair shops [15], [32]. Circular Economy is not well integrated yet into repair shops strategies, however, some authors present it as an opportunity to deal with the waste of resources by reintegrating the scraps into the product chain value [7]. Indeed Circular strategies such as remanufacturing, reuse, repurposing or recycling can provide repairables necessary in the repair shops [48]. There are already many methods to increase the productivity of the repair shops and, with Circular Economy; it is possible, by closing material loops, to make repair shops more sustainable [9]. The orientation for future research can be a better implementation of Circular strategies into the repair shops and the evaluation of their performances. It can be very useful for the practitioners to know whenever circular strategies are profitable for companies.

TABLE VIII. JOURNALS WITH THE STUDIED ARTICLES

\begin{tabular}{|c|c|c|}
\hline References & Journals & $\begin{array}{l}\text { Circular } \\
\text { Economy }\end{array}$ \\
\hline $\begin{array}{c}\text { [2], [3], [4], } \\
{[9],[15],[20],} \\
{[28],[33],[47]}\end{array}$ & $\begin{array}{c}\text { International Journal Of Production } \\
\text { Economics }\end{array}$ & - \\
\hline $\begin{array}{c}{[8],[14],[19],} \\
{[23],[35]}\end{array}$ & European Journal Of Operational Research & \\
\hline$[22],[32],[43]$ & Annals Of Operations Research & \\
\hline [36], [42], [45] & Computers \& Operations Research & \\
\hline [21], [39] & $\begin{array}{c}\text { Asia-pacific Journal Of Operational } \\
\text { Research }\end{array}$ & - \\
\hline [18], [46] & Or Spectrum & \\
\hline [16], [41] & $\begin{array}{c}\text { Journal Of The Operational Research } \\
\text { Society }\end{array}$ & \\
\hline [30], [50] & $\begin{array}{l}\text { International Journal Of Production } \\
\text { Research }\end{array}$ & \\
\hline [31], [52] & Omega & \\
\hline [6], [17] & Reliability Engineering \& System Safety & \\
\hline [10] & Energies & - \\
\hline [11] & $\begin{array}{c}\text { Journal Of Manufacturing Technology } \\
\text { Management }\end{array}$ & \\
\hline [25] & Journal Of Artificial Intelligence Research & \\
\hline [26] & $\begin{array}{c}\text { Journal Of Loss Prevention In The Process } \\
\text { Industry }\end{array}$ & \\
\hline [27] & IIE Transactions & \\
\hline [29] & Applied Mathematical Modelling & \\
\hline [34] & $\begin{array}{l}\text { International Journal Of Advanced } \\
\text { Manufacturing Technology }\end{array}$ & \\
\hline [37] & IEEE Transactions On Reliability & \\
\hline [38] & $\begin{array}{l}\text { IEEE Transactions On Automation Science } \\
\text { And Engineering }\end{array}$ & - \\
\hline
\end{tabular}

\begin{tabular}{|c|c|c|}
\hline$[40]$ & Management Science & \\
\hline$[44]$ & Computers \& Industrial Engineering & \\
\hline$[49]$ & Journal Of Operations Management & \\
\hline$[5]$ & $\begin{array}{c}\text { Surveys In Operations Research And } \\
\text { Management Science }\end{array}$ & \\
\hline$[51]$ & Naval Research Logistics & \\
\hline$[53]$ & $\begin{array}{r}\text { International Journal Of Computational } \\
\text { Intelligence Systems }\end{array}$ & \\
\hline$[48]$ & $\begin{array}{r}\text { European Journal Of Sustainable } \\
\text { Development }\end{array}$ & \\
\hline
\end{tabular}

\section{ACKNOWLEDGMENT}

This work has been supported by the French government; through the Universite Grenoble Alpes and the IDEX Grenoble (Cross Disciplinary Program Circular) with the reference number C7H-ID17-PR28-CIRCULARWP1.

\section{REFERENCES}

[1] L. Wang, J. Chu and W. Mao, "An optimum condition-based replacement and spare provisioning policy based on Markov chains". Journal of Quality in Maintenance Engineering, vol. 14, pp. 387-401, 2008.

[2] A. Sleptchenko, H. H. Turan, S. Pokharel, and T. Y. ElMekkawy, "Cross-training policies for repair shops with spare part inventories," International Journal of Production Economics, vol. 209, pp. 334-345, 2019.

[3] M. A. Driessen, G. J. van Houtum, W. H. M. Zijm, and W. D. Rustenburg, "Capacity assignment in repair shops with high material uncertainty," International Journal of Production Economics, vol. 221, p. 107484,2020 .

[4] H. G. H. Tiemessen and G. J. van Houtum, "Reducing costs of repairable inventory supply systems via dynamic scheduling," International Journal of Production Economics, vol. 143, no. 2, pp. 478-488, 2013.

[5] R. J. I. Basten and G. J. van Houtum, "System-oriented inventory models for spare parts," Surveys in Operations Research and Management Science, vol. 19, no. 1, pp. 34-55, 2014.

[6] Z. Simeu-Abazi and A. A. Ahmad, "Optimisation of distributed maintenance: Modelling and application to the multi-factory production," Reliability Engineering \& System Safety, vol. 96, no. 11, pp. 1564-1575, 2011.

[7] "What is the circular economy?" [Online]. Available: https://www.ellenmacarthurfoundation.org/circular-economy/what-isthe-circular-economy. [Accessed: 26-Mar-2020].

[8] M. A. J. Smith and R. Dekker, "Preventive maintenance in a 1 out of $n$ system: The uptime, downtime and costs," European Journal of Operational Research, vol. 99, no. 3, pp. 565-583, 1997.

[9] R. Kleber, S. Zanoni, and L. Zavanella, "On how buyback and remanufacturing strategies affect the profitability of spare parts supply chains," International Journal of Production Economics, vol. 133, no. 1, pp. 135-142, 2011.

[10] S. Türkeli, B. Huang, A. Stasik, and R. Kemp, "Circular Economy as a Glocal Business Activity: Mobile Phone Repair in the Netherlands, Poland and China," Energies, vol. 12, no. 3, p. 498, Feb. 2019.

[11] Z. Simeu-Abazi, M. Di Mascolo, and E. Gascard, "Queuing networkbased methodology for designing and assessing performance of centralized maintenance workshops," Jnl of Manu Tech Mnagmnt, vol. 25, no. 4, pp. 510-527, Apr. 2014.

[12] J. Dibbern, T. Goles, R. Hirschheim, and B. Jayatilaka, "Information systems outsourcing: a survey and analysis of the literature," SIGMIS Database, vol. 35, no. 4, pp. 6-102, Nov. 2004. 
[13] "SJR: Scientific Journal Rankings." [Online]. Available: https://www.scimagojr.com/journalrank.php? [Accessed: 26-Mar2020].

[14] R. C. H. Chua, G. D. Scudder, and A. V. Hill, "Batching policies for a repair shop with limited spares and finite capacity," European Journal of Operational Research, vol. 66, no. 1, pp. 135-147, 1993.

[15] A. Sleptchenko, M. C. van der Heijden, and A. van Harten, "Effects of finite repair capacity in multi-echelon, multi-indenture service part supply systems," International Journal of Production Economics, vol. 79, no. 3, pp. 209-230, 2002.

[16] M. C. Mabini and A. H. Christer, "Controlling multi-indenture repairable inventories of multiple aircraft parts," Journal of the Operational Research Society, vol. 53, no. 12, pp. 1297-1307, 2002.

[17] K. S. de Smidt-Destombes, M. C. van der Heijden, and A. van Harten, "On the availability of a k-out-of-N system given limited spares and repair capacity under a condition based maintenance strategy," Reliability Engineering \& System Safety, vol. 83, no. 3, pp. 287-300, 2004.

[18] L. Spanjers, J. C. W. van Ommeren, and W. H. M. Zijm, "Closed loop two-echelon repairable item systems," OR Spectrum, vol. 27, no. 2-3, pp. 369-398, 2005.

[19] A. Sleptchenko, M. C. van der Heijden, and A. van Harten, "Using repair priorities to reduce stock investment in spare part networks," European Journal of Operational Research, vol. 163, no. 3, pp. 733750, 2005.

[20] K. S. de Smidt-Destombes, M. C. van der Heijden, and A. van Harten, "Availability of -out-of- systems under block replacement sharing limited spares and repair capacity," International Journal of Production Economics, vol. 107, no. 2, pp. 404-421, 2007.

[21] I. J. B. F. Adan, A. Sleptchenko, and G. J. Van Houtum, "Reducing costs of spare parts supply systems via static priorities," Asia Pac. J. Oper. Res., vol. 26, no. 04, pp. 559-585, 2009.

[22] N. Safaei, D. Banjevic, and A. K. S. Jardine, "Workforce-constrained maintenance scheduling for military aircraft fleet: a case study," Ann Oper Res, vol. 186, no. 1, pp. 295-316, 2011.

[23] P. Sahba and B. Balciog lu, "The impact of transportation delays on repairshop capacity pooling and spare part inventories," European Journal of Operational Research, vol. 214, no. 3, pp. 674-682, 2011.

[24] Z. Simeu-Abazi, M. D. Mascolo, and E. Gascard, "Performance evaluation of centralized maintenance workshop by using Queuing Networks," IFAC Proceedings Volumes, vol. 45, no. 31, pp. 175-180, Jan. 2012.

[25] M. Aramon and J. Beck, "Scheduling a Dynamic Aircraft Repair Shop with Limited Repair Resources," Journal of Artificial Intelligence Research, vol. 47, Feb. 2014

[26] A. Azadeh, S. Motevali Haghighi, S. M. Asadzadeh, and H. Saedi, "A new approach for layout optimization in maintenance workshops with safety factors: The case of a gas transmission unit," Journal of Loss Prevention in the Process Industries, vol. 26, no. 6, pp. 1457-1465, 2013.

[27] P. Sahba, B. Balciog̃lu, and D. Banjevic, "Spare parts provisioning for multiple k -out-of- $\mathrm{n}$ :G systems," IIE Transactions, vol. 45, no. 9, pp. 953-963, 2013.

[28] M. Y. Jaber, S. Zanoni, and L. E. Zavanella, "Economic order quantity models for imperfect items with buy and repair options," International Journal of Production Economics, vol. 155, pp. 126-131, 2014.

[29] B. K. Kim and D. H. Lee, "The M/G/1 queue with disasters and working breakdowns," Applied Mathematical Modelling, vol. 38, no. 5-6, pp. 1788-1798, 2014.

[30] G. C. Lin, A. Wu, D.-C. Gong, B. Huang, and W.-N. Ma, "On a multiproduct lot scheduling problem subject to an imperfect process with standby modules," International Journal of Production Research, vol. 52, no. 8, pp. 2243-2257, Apr. 2014.

[31] W. van Jaarsveld, T. Dollevoet, and R. Dekker, "Improving spare parts inventory control at a repair shop," Omega, vol. 57, pp. 217-229, 2015.

[32] N. C. Buyukkaramikli, H. P. G. van Ooijen, and J. W. M. Bertrand, "Integrating inventory control and capacity management at a maintenance service provider," Ann Oper Res, vol. 231, no. 1, pp. 185206, 2015.

[33] A. A. Taleizadeh, M. P. S. Khanbaglo, and L. E. Cárdenas-Barrón, “An EOQ inventory model with partial backordering and reparation of imperfect products," International Journal of Production Economics, vol. 182, pp. 418-434, 2016.

[34] A. Azadeh, S. F. Ghaderi, S. Pashapour, A. Keramati, M. R. Malek, and M. Esmizadeh, "A unique fuzzy multivariate modeling approach for performance optimization of maintenance workshops with cognitive factors," Int J Adv Manuf Technol, vol. 90, no. 1-4, pp. 499-525, 2017.

[35] J. Arts, "A multi-item approach to repairable stocking and expediting in a fluctuating demand environment," European Journal of Operational Research, vol. 256, no. 1, pp. 102-115, 2017.

[36] H. H. Turan, A. Sleptchenko, S. Pokharel, and T. Y. ElMekkawy, "A sorting based efficient heuristic for pooled repair shop designs," Computers \& Operations Research, vol. 117, p. 104887, May 2020.

[37] M. Assadi, M. Mobin, H. Cheraghi, and Z. Li, "An Algorithm for Performance Evaluation of Closed-Loop Spare Supply Systems With Generally Distributed Failure and Repair Times," IEEE Trans. Rel., vol. 68, no. 2, pp. 678-688, 2019.

[38] P. B. Luh, D. Yu, S. Soorapanth, A. I. Khibnik, and R. Rajamani, "A Lagrangian Relaxation Based Approach to Schedule Asset Overhaul and Repair Services," IEEE Trans. Automat. Sci. Eng., vol. 2, no. 2, pp. 145-157, 2005.

[39] B. Li, X. Li, W. Guo, and S. Wu, "A generalized stochastic petri-net model for performance analysis and allocation optimization of a particular repair system," Asia Pac. J. Oper. Res., vol. 30, no. 01, p. $1250042,2013$.

[40] G. D. Scudder, "Priority Scheduling and Spares Stocking Policies for a Repair Shop: The Multiple Failure Case," Management Science, vol. 30, no. 6, pp. 739-749, Jun. 1984.

[41] A. Sleptchenko, M. van der Heijden, and A. Harten, "Trade-off between inventory and repair capacity in spare part networks," Journal of the Operational Research Society, vol. 54, pp. 263-272, Mar. 2003.

[42] J. C. W. van Ommeren, A. F. Bumb, and A. V. Sleptchenko, "Locating repair shops in a stochastic environment," Computers \& Operations Research, vol. 33, no. 6, pp. 1575-1594, 2006.

[43] W. K. Liang, B. Balcıog̃lu, and R. Svaluto, "Scheduling policies for a repair shop problem," Ann Oper Res, vol. 211, no. 1, pp. 273-288, 2013.

[44] H. H. Turan, A. Sleptchenko, S. Pokharel, and T. Y. ElMekkawy, "A clustering-based repair shop design for repairable spare part supply systems," Computers \& Industrial Engineering, vol. 125, pp. 232-244, 2018.

[45] M. Dreyfuss, Y. Giat, and A. Stulman, "An analytical approach to determine the window fill rate in a repair shop with cannibalization," Computers \& Operations Research, vol. 98, pp. 13-23, 2018.

[46] P. Sahba, B. Balcıog̃lu, and D. Banjevic, "Multilevel rationing policy for spare parts when demand is state dependent," OR Spectrum, vol. 40, no. 3, pp. 751-780, 2018.

[47] H. van Ooijen, J. W. M. Bertrand, and N. C. Buyukkaramikli, "Coordinating failed goods collecting and repair capacity policies in the maintenance of commoditized capital goods," International Journal of Production Economics, vol. 208, pp. 29-42, 2019.

[48] H. Riisgaard, M. Mosgaard, and K. O. Zacho, "Local Circles in a Circular Economy - the Case of Smartphone Repair in Denmark," European Journal of Sustainable Development, vol. 5, no. 1, pp. 109109, Feb. 2016.

[49] G. D. Scudder, "An evaluation of overtime policies for a repair shop," Journal of Operations Management, vol. 6, no. 1, pp. 87-98, 1985.

[50] V. D. R. Guide, R. Srivastava, and M. E. Kraus, "Priority scheduling policies for repair shops," International Journal of Production Research, vol. 38, no. 4, pp. 929-950, 2000.

[51] J. Keizers, I. Adan, and J. van der Wal, "A queuing model for due date control in a multiserver repair shop," Naval Research Logistics, vol. 48, no. 4, pp. 281-292, 2001.

[52] G. D. Scudder and R. Chua, "Determining overtime policies for a repair shop," Omega, vol. 15, no. 3, pp. 197-206, 1987.

[53] N. Shivasankaran, P. S. Kumar, G. Nallakumarasamy, and K. V. Raja, "Repair shop job scheduling with parallel operators and multiple constraints using simulated annealing," International Journal of Computational Intelligence Systems, vol. 6, no. 2, pp. 223-233, 2013. 